\title{
EVALUATION OF A NEW TRUCK-MOUNTED ULV SPRAYING MACHINE WITH BACILLUS THURINGIENSIS VAR. ISRAELENSIS AGAINST LARVAL CULEX QUINQUEFASCIATUS
}

\author{
LEI LUO', MARCIA K. GAINES, AND RUI-DE XUE \\ 'Anastasia Mosquito Control District, 120 EOC Drive, \\ St. Augustine, FL, USA 32092, USA \\ Guangzhou City's Centre for Disease Control and Prevention, \\ Guangzhou, China
}

Guest Editor: M. Farooq

\begin{abstract}
A field study about the effectiveness of a new truck-mounted ultra-low-volume (ULV) machine against larval Culex quinquefasciatus Say was conducted at Anastasia Mosquito Control District of St. Johns County, St. Augustine, FL, during the summer of 2017. Cx. quinquefasciatus larvae were treated using a ground application at different concentrations of Bti using a new truck-mounted ULV sprayer with a horizontal nozzle. Mortality of larvae was recorded after $24 \mathrm{~h}$, and droplet sizes were measured. Overall, Bti sprayed by the new truck-mounted ULV spraying machine at a concentration of $2.625 \mathrm{mg} / \mathrm{L}$ resulted in the highest mortality of mosquito larvae. The results indicate that the Bti concentrations of $0.875 \mathrm{mg} / \mathrm{L}$ and $0.065 \mathrm{mg} / \mathrm{L}$ resulted in a significant difference in mean larval mortality between each distance from the spray line $(\mathrm{P}<0.05)$, while the mortality by the other 3 concentrations $(0.477 \mathrm{mg} / \mathrm{L}, 2.625$ $\mathrm{mg} / \mathrm{L}$, and $5.25 \mathrm{mg} / \mathrm{L})$ tested did not. The LC50 and LC90 of Bti against larvae were $0.261 \mathrm{mg} / \mathrm{L}(0.239 \sim 0.286)$ and $1.687 \mathrm{mg} / \mathrm{L}(1.481 \sim 1.922)$, respectively. The coverage (swath) of the spray by the new ULV machine showed that the Bti could be sprayed at least 33 meters away with a 20 meter width. Therefore, the new truck-mounted ULV spraying machine with liquid Bti could be used to treat a large area effectively and efficiently and as an additional tool for the control of mosquito larvae.
\end{abstract}

Key Words: Culex quinquefasciatus, larvae, mortality, Bacillus thuringiensis israelensis, truck-mounted ULV spraying machine

\section{INTRODUCTION}

Mosquitoes are a nuisance and many play potential vectors of human diseases, such as malaria, filariasis, and arboviral diseases (dengue fever, Chikungunya, West Nile fever, Zika, and yellow fever) (Mittal 2003). Integrated vector management (IVM), targeting both larval and adult mosquitoes, has been considered the most effective measure for mosquito elimination (Imbahale et al. 2012). Vector control efforts typically target the immature stages and controlling their population is an important task for public health (Lucia et al. 2009). Applying larvicides in breeding sites is still considered a priority for mosquito control (Williams et al. 2014). The traditional approaches to lar- val control are to find the larval sources and empty/treat those using hand-held sprayers or truck-mounted sprayers with different formulations of larvicides. Previous research illustrated the effectiveness of a hand-pump and gasoline powered backpack sprayer (Sandoski et al. 1985), truck-mounted cold aerosol fogger, Buffalo Turbine mist sprayer (Williams et al. 2014), ULV (Lam et al, 2010, Harwood et al. 2016), and even aerial spraying (Pruszynski et al. 2017) for the control of mosquito larvae.

Bacillus thuringiensis israelensis (Bti), a bacterial larvicide which is highly target specific and appropriate for wide area spraying, is used to control mosquito and black fly larvae (Yap et al. 1997). Different formulations of Bti have been successfully used in 
ground applications with hand-pump backpack sprayers/misters, and thermal foggers (Dunford et al. 2014). These applications have a limited utility for large scale control. Truck-mounted cold aerosol foggers have been studied for the large scale control of mosquito larvae over time (Williams et al. 2014). However, their utility has still to be appreciated. Thus, continuous search and evaluation of new effective and economic spray machines for efficient control should concern professionals.

The new truck-mounted ULV spray machine used in this project has been evaluated for barrier treatments (Fulcher et al 2015) but has not been tested for the application of any kind of larvicides. The objectives of this study were to 1) determine whether the new truck-mounted ULV spray machine can be used to apply liquid Bti to control larval Culex quinquefasciatus Say in artificial containers, 2) determine the optimal dilution of Bti for larval control by using the new machine, and 3) measure the distance and width (swath) reached by the new machine.

\section{MATERIALS AND METHODS}

Study site and mosquito larvae. This study was conducted at the Anastasia Mosquito Control District (AMCD), 120 EOC Drive, St. Augustine, FL, on an unpaved and grassy ground. A susceptible strain of $C x$. quinquefasciatus Say larvae was provided by the AMCD insectary. Late third- or early fourth-instar larvae were used for the study.

Insecticide. A commercial biolarvicide named AQUABAC@xt (a.i. Bacillus thuringiensis var. israelensis (Bti), Becker Microbial Products, Inc. Plantation, FL), which contained $8 \%$ Bacillus thuringiensis subspecies israelensis Strain BMP 144 solids, spores and insecticidal toxins, was used for the experiment. The formulation of the biolarvicide is an aqueous suspension. The label application instructions specify the rate of AQUABAC@xt required for control with a sufficient amount of water to provide thorough coverage of the target area when it is applied in conventional aerial and ground application equipment. The formulation was diluted in purified water at 1:0, 1:1, 1:5, 1:10 and 1:80 (Bti:Water) ratios to provide active ingredient concentrations of $5.250 \mathrm{mg} / \mathrm{L}$, $2.625 \mathrm{mg} / \mathrm{L}, 0.875 \mathrm{mg} / \mathrm{L}, 0.477 \mathrm{mg} / \mathrm{L}$ and $0.065 \mathrm{mg} / \mathrm{L}$, respectively.

Equipment. The new truck-mounted ULV spray machine (model: LR-4P, 4 nozzles installed on 4 spray heads, American LongRay, Inc., San Francisco, CA) was evaluated in this study. The machine has excellent atomization, quick diffusion, and creates a dense fog that penetrates into spaces and lingers in the air for a longer time. Also, the spray machine heads can be adjusted to swivel 360 degrees horizontally and 180 degrees vertically by manual or remote control. This Truckmounted cold fogger can spray a variety of chemicals used for public health protection, disinfection, vector control, pest control, and crop protection. This equipment produced droplets at a volume median diameter (Dv0.5) of $14.3 \mu \mathrm{m}$ and 90th percentile (Dv0.9) of $30.4 \mu \mathrm{m}$ while spraying water.

Field test. Between 20-30 mosquito larvae were collected using a plastic aspirator from a stock plastic pan $(50 \mathrm{~cm} \mathrm{~L} \times 38 \mathrm{~cm} \mathrm{~W}$ $\times 7 \mathrm{~cm} \mathrm{H})$ ) and transferred to each of nine white plastic containers $(30 \mathrm{~cm} \mathrm{~L} \times 18 \mathrm{~cm}$ $\mathrm{W} \times 10 \mathrm{~cm} \mathrm{H}$ ) with $2 \mathrm{~L}$ purified water. The dilutions were sprayed with the new truckmounted ULV spray machine at a flow rate of $92 \mathrm{ml} / \mathrm{min}$. At a travel speed of $16 \mathrm{Km} / \mathrm{h}$, the certified pesticide sprayer applied the different Bti dilutions at an application rate of $37 \mathrm{ml} / \mathrm{ha}$.

For the optimal concentration in each treatment, all four nozzle heads were angled horizontally (parallel to the ground). The effectiveness of each application was assessed by the mortality of $C x$. quinquefasciatus larvae at $24 \mathrm{~h}$ post treatment.

Three rows of larval containers (from No 1 to No 9) at $2 \mathrm{~m}$ apart were placed up to 15 $\mathrm{m}$ perpendicular to the spray line. In each row, 3 containers were separated at 5, 10, and $15 \mathrm{~m}$ away from the spray line. Alongside treatment container No. 3, 7, and 9, a Florida Latham Bond spinner (model 319; John W. Hock Company, Gainesville, FL) using a $3 \mathrm{~mm} \times 75 \mathrm{~mm}$ Teflon ${ }^{\circledR}$ coated slide was deployed to determine spray droplet 
sizes. Larval containers were placed on the ground and the spinners were hung at 1.2 $m$ height on the posts. Spray application of each concentration was replicated three times at the same site, with at least one week interval between trials. For each replication, three control larval containers were deployed for 15 minutes at the first row of the spray zone ( $5 \mathrm{~m}$ from the spray line) and were removed before start of the spray. Test larval containers and spinner slides were placed in the field immediately before spray. The truck-mounted ULV sprayer was operated at a speed of $16 \mathrm{Km} / \mathrm{h}$ from $17 \mathrm{~m}$ before the test area and ended $17 \mathrm{~m}$ past the test area. Spinner slides and test larval containers were removed from the field at $5 \mathrm{~min}$ and $15 \mathrm{~min}$, respectively post-treatment. The air temperature $\left(25-28{ }^{\circ} \mathrm{C}\right)$, relative humidity $(65-90 \%)$, wind speed $(3-15 \mathrm{Km} / \mathrm{hr})$, and wind direction were recorded at $1.5 \mathrm{~m}$ above ground during the field tests. After applications, all larval containers were transferred to the AMCD laboratory and larval mortality counts were taken at $24 \mathrm{~h}$ post treatment. All slides were transported to the laboratory for droplet size measurements. Droplets on the slides were measured with DropVision system (Leading Edge, Fletcher, NC) and droplets statistics were determined with the associated software.

The distance and width (swath) reached by the new truck-mounted ULV sprayer was tested using circular plastic disks set in an array at fixed distances. The machine's tank was filled with a mixture of water and red dye to visually detect the swath on the disks. Four rows of collectors, $7 \mathrm{~m}$ apart, were set up to $33 \mathrm{~m}$ perpendicular to the sprayer on either direction. In each row, four, $4.72 \mathrm{~cm}$ diameter circular plastic disks, each with a piece of white test filter paper, were held on the ground at 13, 20, 27, and $33 \mathrm{~m}$ from the sprayer. The sprayer was oriented towards the test array and was stationed in the center of the array. Two tests were conducted. The first test was for all four nozzle heads sprayed toward the same direction horizontally (parallel to the ground). The second test divided the four nozzles into two groups, one set spraying horizontally (parallel to the ground) to one direction and the other oriented toward the opposite direction. Each test spray lasted for 10 seconds. All the white test filter papers were collected and examined under the microscope for the red dye to assess the distance and width (swath) which the sprayer can reach.

Date analysis. The larval mortality was corrected by Abbott's formula (Abbott 1925) when a $5 \%$ or more mortality was detected in the control group. The values for larval mortality of each replicate in each test were calculated and the dose-mortality response was assessed using the R-script BioRssay package, which computes the doses of insecticides killing 50\% (LC50) and 90\% (LC90) of the tested larvae. For the comparison of 24 hour mortality between the 5 different concentrations $(5.250 \mathrm{mg} / \mathrm{L}, 2.625 \mathrm{mg} / \mathrm{L}$, $0.875 \mathrm{mg} / \mathrm{L}, 0.477 \mathrm{mg} / \mathrm{L}$ and $0.065 \mathrm{mg} / \mathrm{L})$ and 3 distances $(5 \mathrm{~m}, 10 \mathrm{~m}$, and $15 \mathrm{~m})$ from the spray line with droplet Dv0.5, nonparametric Kruskal-Wallis analysis and multifactor analysis of ANOVA were conducted, respectively. A posteriori of Tukey HSD means multiple comparison tests was conducted by using Software STATGRAPHICS Plus for Windows Version 4.0-CorpSGWIN P®. Analysis was conducted with $\mathrm{R}$ software (Version 3.4.1). A p-value of $<0.05$ was considered statistically significant.

\section{RESULTS}

The Bti dilution ratio by water (1:0, 1:1, $1: 5,1: 10$, and $1: 80$ ) was converted to the actual active ingredient concentrations of $5.250 \mathrm{mg} / \mathrm{L}, 2.625 \mathrm{mg} / \mathrm{L}, 0.875 \mathrm{mg} / \mathrm{L}, 0.477$ $\mathrm{mg} / \mathrm{L}$ and $0.065 \mathrm{mg} / \mathrm{L}$, respectively. There was a significant difference in $24 \mathrm{~h}$ larval mortality between each test and control at all test concentrations $(P<0.05)$ (Fig. 1).

As shown in Table 1, there was a significant difference in $24 \mathrm{hr}$ mortality between different Bti concentrations $\left(\chi^{2}=77.98, P<0.001\right)$. The concentration of $2.625(1: 1) \mathrm{mg} / \mathrm{L}$ resulted in the highest larval mortality $(100.00 \%)$, while $0.065 \mathrm{mg} / \mathrm{L}$ resulted in the lowest larval mortality $(24.26 \%)$. Tukey multiple comparison tests identified that the mortalities from different test concentrations were significantly 


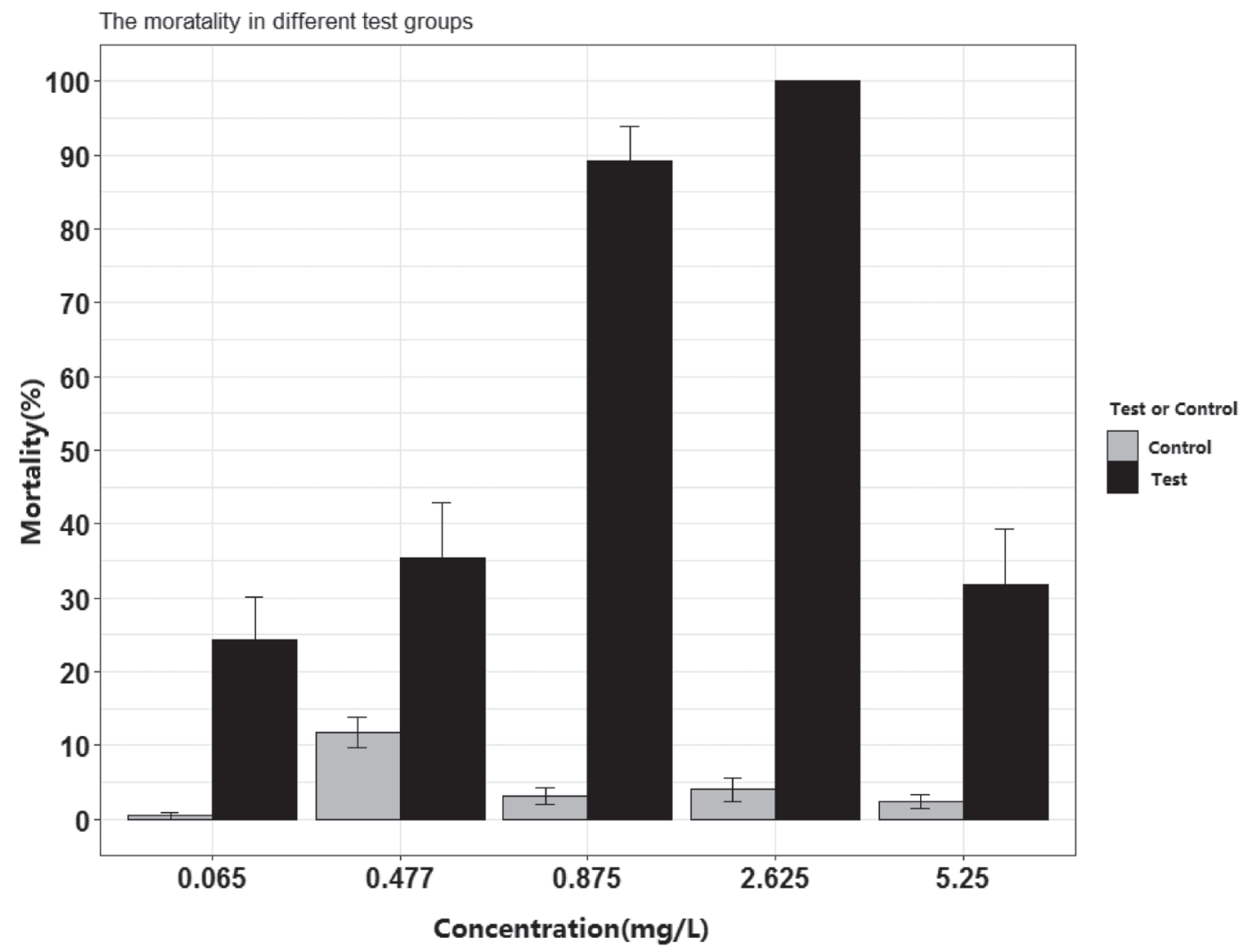

Fig. 1. Mean mortality $(\% \pm \mathrm{SD})$ of larvae caused by Bti at different concentrations sprayed by the new truckmounted ULV spraying machine, compared with mortality in control group

different from each other. The mortality from $0.875 \mathrm{mg} / \mathrm{L}$ and $2.625 \mathrm{mg} / \mathrm{L}$ was generally similar and were significantly higher than those of the other three concentrations tested $(0.065 \mathrm{mg} / \mathrm{L}<5.250 \mathrm{mg} / \mathrm{L}<0.477 \mathrm{mg} / \mathrm{L})$. The LC50 and LC90 of the larvae for Bti were $0.261 \mathrm{mg} / \mathrm{L}(0.239 \sim 0.286 \mathrm{mg} / \mathrm{L})$ and 1.687 $\mathrm{mg} / \mathrm{L}(1.481 \sim 1.922 \mathrm{mg} / \mathrm{L})$, respectively, computed by the equation $\mathrm{Y}=1.658+2.713 * \mathrm{X}$ which was assessed by the dose-mortality response regression analysis.

The comparison of mean larval mortality between distances from the spray line from each concentration (Table 2) indicated that distance significantly affected mortality from the concentrations of $5.250 \mathrm{mg} / \mathrm{L}$ and $0.875 \mathrm{mg} / \mathrm{L}(P<0.05)$. However, from the other 3 concentrations $(0.477 \mathrm{mg} / \mathrm{L}, 2.625$ $\mathrm{mg} / \mathrm{L}$, and $0.065 \mathrm{mg} / \mathrm{L})$ distance did not significantly affect mortality. The concentrations of $0.875 \mathrm{mg} / \mathrm{L}$ and $2.625 \mathrm{mg} / \mathrm{L}$ at all distances produced $100 \%$ larval mortality except for the $15 \mathrm{~m}$ distance of $0.875 \mathrm{mg} / \mathrm{L}$ concentration, which produced $67.43 \%$ larval mortality only. Other concentrations at

Table 1. Mean larval mortality at $24 \mathrm{hr}$ exposure to different concentrations of Bti sprayed by the new truck-mounted ULV spraying machine.

\begin{tabular}{lccccccc}
\hline \hline Concentration & $\mathrm{N}$ & Mean mortality\% & SD & SE & $95 \% \mathrm{CI}$ & K-W $\left(\chi^{2}\right.$ value $)$ & $\mathrm{P}$ \\
\hline $0.065 \mathrm{mg} / \mathrm{L}$ & 27 & 24.26 & 30.15 & 5.80 & $12.33 \sim 36.19$ & 77.979 & 0.000 \\
$0.477 \mathrm{mg} / \mathrm{L}$ & 27 & 35.44 & 38.36 & 7.38 & $20.26 \sim 50.62$ & & \\
$0.875 \mathrm{mg} / \mathrm{L}$ & 27 & 89.14 & 24.73 & 4.76 & $79.36 \sim 98.92$ & & \\
$2.625 \mathrm{mg} / \mathrm{L}$ & 27 & 100 & 0.00 & 0.00 & $100 \sim 100$ & & \\
$5.250 \mathrm{mg} / \mathrm{L}$ & 27 & 31.85 & 38.55 & 7.42 & $16.6 \sim 47.1$ & & \\
\hline
\end{tabular}


Table 2. Comparison of larval $24 \mathrm{~h}$ mortality at different distances from the spray line after exposure to different concentrations of Bti sprayed by the new truck-mounted ULV sprayer.

\begin{tabular}{|c|c|c|c|c|c|c|c|c|}
\hline Concentration & $\begin{array}{l}\text { Distance } \\
\text { from spay line }\end{array}$ & $\mathrm{N}$ & Mean mortality & SD & $\mathrm{SE}$ & CI & $\mathrm{K}-\mathrm{W}\left(\chi^{2}\right.$ value $)$ & $\mathrm{P}$ \\
\hline \multirow[t]{3}{*}{$0.065 \mathrm{mg} / \mathrm{L}$} & $5 \mathrm{~m}$ & 9 & 39.34 & 31.08 & 10.36 & $15.45-63.23$ & 4.970 & 0.083 \\
\hline & $10 \mathrm{~m}$ & 9 & 10.91 & 13.71 & 4.57 & $0.37-21.45$ & & \\
\hline & $15 \mathrm{~m}$ & 9 & 22.52 & 36.63 & 12.21 & $0-50.68$ & & \\
\hline \multirow[t]{3}{*}{$0.477 \mathrm{mg} / \mathrm{L}$} & $5 \mathrm{~m}$ & 9 & 39.91 & 38.63 & 12.88 & $10.21-69.61$ & 0.088 & 0.916 \\
\hline & $10 \mathrm{~m}$ & 9 & 33.92 & 41.20 & 13.73 & $2.25-65.59$ & & \\
\hline & $15 \mathrm{~m}$ & 9 & 32.51 & 39.47 & 13.16 & $2.17-62.85$ & & \\
\hline \multirow[t]{3}{*}{$0.875 \mathrm{mg} / \mathrm{L}$} & $5 \mathrm{~m}$ & 9 & 100 & 0.00 & 0.00 & $100-100$ & 11.661 & 0.003 \\
\hline & $10 \mathrm{~m}$ & 9 & 100 & 0.00 & 0.00 & $100-100$ & & \\
\hline & $15 \mathrm{~m}$ & 9 & 67.43 & 34.52 & 11.51 & $40.9-93.96$ & & \\
\hline \multirow[t]{3}{*}{$2.625 \mathrm{mg} / \mathrm{L}$} & $5 \mathrm{~m}$ & 9 & 100 & 0.00 & 0.00 & $100-100$ & - & - \\
\hline & $10 \mathrm{~m}$ & 9 & 100 & 0.00 & 0.00 & $100-100$ & & \\
\hline & $15 \mathrm{~m}$ & 9 & 100 & 0.00 & 0.00 & $100-100$ & & \\
\hline \multirow[t]{3}{*}{$5.250 \mathrm{mg} / \mathrm{L}$} & $5 \mathrm{~m}$ & 9 & 44.62 & 44.21 & 14.74 & 10.63-78.61 & 0.751 & 0.482 \\
\hline & $10 \mathrm{~m}$ & 9 & 23.44 & 36.61 & 12.2 & $0-51.58$ & & \\
\hline & $15 \mathrm{~m}$ & 9 & 27.49 & 35.37 & 11.79 & $0.30-54.68$ & & \\
\hline
\end{tabular}

all the distances produced similar mortality, which were lower than $50 \%$.

There was a significant difference in droplet size Dv0.5 between different test concentrations $(P<0.05)$. At the $0.065 \mathrm{mg} / \mathrm{L}$ concentration, the droplet size Dv0.5 was the biggest $(31.49 \mu \mathrm{m})$, but the smallest $(18.42$ $\mu \mathrm{m})$ was at the concentration of $2.625 \mathrm{mg} / \mathrm{L}$ (Table 3).

During the first spray test for distance and width (swath), all four nozzles sprayed in the same direction at the same time under SE $1 \mathrm{mph}$ wind. After analysis using light microscopy, 10 out of $16(62.50 \%)$ plates with white filter paper in this test had been stained with red dye. The number of disks with white filter paper stained in each row were 3, 2, 2 and 3 from 13, 20, 27, and $33 \mathrm{~m}$ away from the truck sprayer, respectively.

When four nozzles were divided into two groups (two in each group) and sprayed towards two opposite direction under SE $2 \mathrm{mph}$ wind, 11 out of $16(68.75 \%)$ plates with white filter paper at the downwind side had been stained and the number of disks with white filter paper stained in each row were 4, 3, 3 and 1 from 13, 20, 27, and 33 $\mathrm{m}$ away from the truck sprayer, respectively. None of plates with white filter paper had been stained at the upwind side. These results indicate that spray reached up to $33 \mathrm{~m}$ in the downwind of the spray and did not travel much to the upwind side.

\section{DISCUSSION}

When liquid is used to treat mosquito breeding sites, such as tidal water, salt marshes, catch basins, and storm water retention areas, we usually use conventional spraying equipment or apply our treatments directly in the breeding sites (Xue and Doyle 2005).

Table 3. Droplet size (Dv0.5) of the liquid Bti at different concentrations sprayed by the new truck-mounted ULV spraying machine.

\begin{tabular}{llcccccc}
\hline \hline concentration & $\mathrm{N}$ & Droplet size(Dv0.5) & SD & SE & CI & chi-square & P \\
\hline $5.250 \mathrm{mg} / \mathrm{L}$ & 27 & 31.92 & 1.48 & 0.28 & $0.90 \sim 2.06$ & 90.29 & 0.000 \\
$0.477 \mathrm{mg} / \mathrm{L}$ & 27 & 24.72 & 2.77 & 0.53 & $1.67 \sim 3.87$ & & \\
$0.875 \mathrm{mg} / \mathrm{L}$ & 27 & 22.58 & 4.01 & 0.77 & $2.42 \sim 5.60$ & & \\
$2.625 \mathrm{mg} / \mathrm{L}$ & 27 & 18.42 & 4.82 & 0.93 & $2.91 \sim 6.73$ & & \\
$0.065 \mathrm{mg} / \mathrm{L}$ & 27 & 31.49 & 4.00 & 0.77 & $2.42 \sim 5.58$ & & \\
\hline
\end{tabular}


Our findings indicate that all 5 Bti concentrations $(5.250 \mathrm{mg} / \mathrm{L}, 2.625 \mathrm{mg} / \mathrm{L}, 0.875$ $\mathrm{mg} / \mathrm{L}, 0.477 \mathrm{mg} / \mathrm{L}$ and $0.065 \mathrm{mg} / \mathrm{L})$, resulted in $24.26 \%-100 \%$ larval mortalities after 24 hours of exposure to liquid Bti $(1,200$ ITU $/ \mathrm{mg}$ ). The significant difference in larval mortality from all concentrations and control and $>90 \%$ mortality in some concentrations suggested that the new cold ULV spraying machine could be used to spray liquid Bti to kill mosquito larvae.

The new ULV spray machine with the highest and the lowest dilution ratios of Bti didn't result in significant mosquito larval mortality. The concentrations of $0.785 \mathrm{mg} / \mathrm{L}$ and $2.625 \mathrm{mg} / \mathrm{L}$ resulting from $1: 5$ and $1: 1$ dilutions, respectively were the suitable for the new machine to spray a large area.

The analysis of the larval mortality at different distances from the spray line suggested that the acceptable larvae mortality of $>80 \%$ within a $15 \mathrm{~m}$ distance from spray could be obtained at the dilution ratio of 1:1 $(2.625 \mathrm{mg} / \mathrm{L})$ or up to $10 \mathrm{~m}$ with dilution ratio of $1: 5(0.875 \mathrm{mg} / \mathrm{L})$.

Droplet size is a very important factor (Harburguer et al. 2012) for killing larvae using Bti (Seleena et al. 1996). In our study, we set three groups of teflon-coated slides atop spinners for droplet size analysis at different distances from the spray line to check the DV0.5. The droplet size data analysis and mortality relationship indicated that the smaller DV0.5 spray resulted in higher larval mortalities.

Additionally, the results of the distance and width reached by the new ULV spray suggests that the farthest distance (swath) should be no more than $33 \mathrm{~m}$ along wind when the new truck-mounted ULV spray machine is fixed at a central position spraying towards one side or two sides with nozzles oriented horizontally. Also, it was shown that the droplets could travel further and were more effective with all four nozzles sprayed towards same direction at the same time than that of subgroups (two nozzles for each group) sprayed towards two opposite direction at the same time. Also the distance and width can be dramatically affected by wind speed and direction from the two opposite directions. But this test was conducted by using dyed water only, and the actual effective distance and width (swath) of the ULV spray machine needs to be addressed further. Finally, the study was conducted in a simulated field with a laboratory- reared sensitive strain of mosquitoes. A large-scale community field test needs to be carried out in the future.

The new truck-mounted ULV spray machine with liquid Bti provided efficient control for mosquito larvae in containers placed on the ground in the field trails. The new ULV spray machine may cover at minimum a $33 \mathrm{~m}$ distance $\mathrm{x} 20 \mathrm{~m}$ width. Bti sprayed with the new truck-mounted ULV spray machine is practical and could be considered as an alternative method for treatment for the large scale control of larval mosquitoes.

\section{ACKNOWLEDGMENTS}

The authors thank C. Bibbs for droplet analysis, D. Dixon for editing \& reviewing the manuscript, C. Mangum for providing mosquito larvae, J. Wynn for calibration of the new machine, and J. Davis for participation in the experiment at the Anastasia Mosquito Control District, St. Augustine, FL.

\section{REFERENCES CITED}

Abbott WS. 1925. A method of computing the effectiveness of an insecticide. JEcon Entomol 18:265-267.

Dunford JC, Stoops CA, Estep AS, Britch SC, Richardson AG, Walker TW, Farooq M, Platt RR, Smith VL, Wirtz RA, Kerce JD. 2014. SR450 and super hawk $\mathrm{XP}$ applications of Bacillus thuringiensis israelensis against Culex quinquefasciatus. J Am Mosq Control Assoc 30:191-198.

Fulcher A, Farooq M, Smith ML, Li CX, Scott JM, Thomson E, Kaufman PE, Xue, RD.2015. Evaluation of a new spraying machine for barrier treatment and penetration of bifenthrin on vegetation against mosquitoes. J Am Mosq Control Assoc 31:85-92.

Harburguer L, Seccacini E, Licastro S, Zerba E, Masuh H. 2012. Droplet size and efficacy of an adulticidelarvicide ultralow-volume formulation on Aedes aegypti using different solvents and spray application methods. Pest Manag Sci 68:137-141.

Harwood JF, Helmey WL, Turnwall BB, Justice KD, Farooq M, Richardson AG. 2016. Controlling Aedes aegypti in cryptic environments with manually carried ultra-low volume and mist blower pesticide applications. J Am Mosq Control Assoc 32:217-223.

Imbahale SS, Githeko A, Mukabana WR, Takken W. 2012. Integrated mosquito larval source management reduces larval numbers in two highland vil- 
lages in western Kenya. BMC Public Health 12, Article \#362.

Lam PH, Boon CS, Yng NY, Benjamin S. 2010. Aedes albopictus control with spray application of Bacillus thuringiensis israelensis, strain AM 65-52. Southeast Asian J Trop Med Public Health 41:1071-1081.

Lucia A, Harburguer L, Licastro S, Zerba E, Masuh H. 2009. Efficacy of a new combined larvicide-adulticidal ultralow volume formulation against Aedes aegypti (Diptera: Culicidae), vector of dengue. Parasitol Res 104:1101-1107.

Mittal P. 2003. Biolarvicides in vector control: challenges and prospects. J Vect Borne Dis 40:20-32.

Pruszynski CA, Hribar LJ, Mickle R, Leal AL. 2017. A large scale biorational approach using Bacillus thuringiensis israeliensis (Strain AM65-52) for managing Aedes aegypti populations to prevent Dengue, Chikungunya and Zika transmission. PLOS One 12(2):e0170079. doi:10.1371/journal. pone.0170079.

Sandoski CA, Yates MM, Olson JK, Meisch MV. 1985. Evaluation of Beecomist-applied Bacillus thuringien- sis (H-14) against Anopheles quadrimaculatus larvae in rice field. JAm Mosq Control Assoc 1:316-319.

Seleena P, Lee HL, Nazni WA, Rohani A, Kadri MS. 1996. Microdroplet application of mosquitocidal Bacillus thuringiensisusing ultra-low-volume generator for the control of mosquitoes. Southeast Asian J Trop Med Public Health 27:628-632.

Williams GM, Faraji A, Unlu I, Healy SP, Farooq M, Gaugler R, Hamilton G, Fonseca DM. 2014. Areawide ground applications of Bacillus thuringiensis var. israelensis for control of Aedes albopictus in residential neighborhoods: from optimization to operation. PLOS one: 9(10):e110035. Doi10.1371/journal. pone.0110035.

Xue RD, Doyle MA. 2005. Evaluation of upstream point treatment in flowing water ditches by aquabact $(\mathrm{Ba}$ cillus thuringiensis var. israelensis) against Culex quinquefasciatus. J Am Mosq Control Assoc 21:234-235.

Yap HH, Chong ASC, Adanan CR, Chong NL, Rohaizat B, Malik AY, Lim SY. 1997. Performance of ULV formulations (Pestguard ${ }^{\circledR}$ 102/Vectobac ${ }^{\circledR}$ 12AS) against three mosquito species. JAm Mosq Control Assoc 13:384-388. 